\title{
Geographical Diversity of Japanese Papilio Butterflies Inferred from the Number of Contact Chemosensillum on the Fifth Foretarsal Segments
}

\section{Takashi A. Inoue ${ }^{\star}$}

Japanese National Institute of Agrobiological Sciences, Ôwashi 1-2, Tsukuba, Ibaraki, Japan

*Corresponding author: Takashi A. Inoue, Japanese National Institute of Agrobiological Sciences, Ôwashi 1-2, Tsukuba, Ibaraki, Japan, Tel: +81-29-838-6106; E-mail: inoueatp@affrc.go.jp

Received date: August 01, 2015; Accepted date: October 09, 2015; Published date: October 07, 2015

Copyright: @ 2015, Inoue TA. This is an open-access article distributed under the terms of the Creative Commons Attribution License, which permits unrestricted use, distribution, and reproduction in any medium, provided the original author and source are credited.

\begin{abstract}
The numbers of contact chemosensillum on ventral side of fifth foretarsal segments of Japanese $P a p i l i o$ butterflies were determined by scanning electron microscope observation. $P$. bianor, $P$. helenus, $P$. protenor and $P$. memnon exhibited geographical diversity for this character among mainland Japan, Amami Islands, Okinawa Islands and Yaeyama Islands populations. This characteristic was useful for reconfirming the geographical variations proposed by the wing color patterns and genetic characteristics of each these species. This characteristic also uncovered hidden geographical variations and phylogenetic structures of $P$. machaon, $P$. xuthus, $P$. maackii, $P$. macilentus and that of $P$. memnon on mainland Japan and that of $P$. protenor on Okinawa Islands. Also discussed are possible causes for the apparent phylogeny disparities between this report and other previous studies including DNA analyses.
\end{abstract}

Keywords: Contact chemosensillum; Lepidoptera; Papilio; Phylogeny; Biodiversity; Japanese

\section{Introduction}

In my previous publication [1], I described the foreleg tarsal morphology of Japanese Papilio butterflies and pointed out that these characteristics are closely related to both phylogeny and host plant selection by females. According to that analysis, I was able to divide ten Japanese Papilio species plus $P$. polyxenes (occurs in north America), $P$. demodocus (occurs in Africa, type species of Princeps) and P. paris (occurs in Southeast Asia, type species of Achillides) into five subgenera: Papilio (P. machaon and $P$. polyxenes), Princeps $(P$. demodocus, $P$. demoleus and $P$. xuthus), Achillides (P. paris, $P$. bianor and $P$. maackii), Menelaides ( $P$. helenus, $P$. polytes, $P$. protenor and $P$. macilentus) and Iliades (P. memnon). This study also showed that females of $P$. (Papilio) species, $P$. (Achillides) maackii, and $P$. (Menelaides) macilentus were distinct for fortarsal morphology differences that are related to their special host plant preferences among the subgenus/genus in which these species belong. I also suggested that certain Papilio species might exhibit geographical diversity on the numbers of contact chemosensillum, but this could not be confirmed because of a lack of samples, in particular for $P$. xuthus from Nansei Islands and P. protenor from Amami Islands [1].

The geographical diversities of Papilio species in Japan have been mainly studied by a large number of amateur researchers. According to [2-11], the description of Japanese Papilio butterflies on mainland Japan (hereafter Hondo) and Nansei Islands (Amami Islands, Okinawa Islands, Daitô Islands, Miyako Islands and Yaeyama Islands) were begun by European researchers during the late 19th and early 20th century. After 1960, Japanese researchers delineated some additional subspecies primarily by their wing color schemes for the small peripheral populations. The geographic diversity of $P$. bianor was derived on the basis of host plant preference [12-20], intersubspecies hybridization [13,14,21-31], morphology [13,21,22,25-27,29,32-43], isozyme analysis [29,44,45], DNA analysis [46-50], photoperiodism [31] and principle analysis of wing shape [51]. The geographical diversity of $P$. protenor has been studied in terms of larval color [52], photoperiodism [53,54], DNA analysis [46] and intersubspecies hybridization $[26,55]$. The geographical diversity of $P$. memnon has been investigated with respect to photoperiodism [56], adult wing shapes [52] and adult wing color schemes [57-59]. Some other species also have been studied in terms of the adult and/or larval color scheme [40,60-64].

After 2005, I undertook a study of the foreleg tarsus morphology of newly obtained Japanese Papilio specimens with a focus on the number of contact chemosensillum present on the ventral surface of the fifth segment. Here, I report these results and discuss the relationship between foreleg morphology and geographical diversity.

\section{Materials and Methods}

New data from 127 male and 161 female forelegs of summer form Japanese Papilio butterflies were added to the data set used in [1] and the total data set was analyzed for this article. With inclusion of the new data, studies included a total of 53 males and 67 females of $P$. machaon, 94 males and 114 females of $P$.xuthus, 4 males and 2 females of $P$. demoleus, 80 males and 89 females of $P$. maackii, 94 males and 100 females of $P$. bianor, 81 males and 86 females of $P$. helenus, 21 males and 24 females of $P$. polytes, 88 males and 90 females of $P$. protenor, 49 males and 44 females of $P$. macilentus, and 56 males and 71 females of $P$. memnon. The method of observation was the same as that of [1]. Excised forelegs were washed in detergent water with sonication for 30 minutes, dried at room temperature, coated with $10-20 \mathrm{~nm}$ of gold and photographed using Scanning Electron Microscope (JEOL JSM-6301F). The number of contact chemosensillum in the fifth foretarsal segment was counted. The ventral spine numbers in the second through fifth foretarsal segments, the number of contact chemosensilla in the second through fourth foretarsal segments, and lengths and widths of the fifth foretarsal 
Citation: Inoue TA (2015) Geographical Diversity of Japanese Papilio Butterflies Inferred from the Number of Contact Chemosensillum on the Fifth Foretarsal Segments. J Biodivers Endanger Species S1: S1.007. doi:10.4172/2332-2543.S1-007

Page 2 of 10

segments were also recorded. Each species was separated into a number of small populations. For grouping of each of these species, the current taxonomy of these species, plant distribution patterns, and geographical history [65-67] were considered. When appropriate, the chemosensilla number means were tested for significant differences among populations of each species according to an F-distribution test $[68,69]$.

\section{Results}

I could confirm the diversity of nine Japanese Papilio species, $P$. machaon, $P$. xuthus, $P$. maackii, $P$. bianor, $P$. helenus, $P$. polytes, $P$. protenor, $P$. macilentus and $P$. memnon, and not of $P$. demoleus. All results were shown in Figures 1-4 and Tables 1-9.

Geographical difference of means of fifth tarsal contact chemosensilla numbers of each Japanese Papilio species.

\begin{tabular}{|l|l|l|}
\hline \multicolumn{2}{|l|}{ P. machaon } & \multicolumn{2}{l|}{} \\
\hline \multirow{3}{*}{ EJ } & Average & EJ \\
\hline \multirow{3}{*}{ WJ } & 25.611 & \\
\cline { 2 - 4 } & 71.935 & \\
\cline { 2 - 4 } & 26.882 & 1.271 \\
\hline
\end{tabular}

Table 1: Diversity of $P$. machaon. Upper: male, Lower: female. Abbreviations on top or left of each row/column e.g. "EJ" or "WJ" are as same as those shown in figure legends. ${ }^{*}$ : the variance between 2 populations is not equal in $5 \%$ normal significance level in Fdistribution. ${ }^{* *}$ : the variance between 2 populations is not equal in $1 \%$ normal significance level in F-distribution.

\begin{tabular}{|c|c|c|c|}
\hline \multicolumn{3}{|c|}{ P. xuthus } & \multirow[b]{2}{*}{ WJ } \\
\hline & Average & EJ & \\
\hline \multirow[b]{2}{*}{ EJ } & 27.824 & & \\
\hline & 69.603 & & \\
\hline \multirow[b]{2}{*}{ WJ } & 25.6 & -2.224 & \\
\hline & 62.651 & $-6.952^{*}$ & \\
\hline \multirow[b]{2}{*}{ sw } & 26.667 & -1.157 & 1.067 \\
\hline & 67.846 & -1.757 & $5.195^{\star \star}$ \\
\hline
\end{tabular}

Table 2: Diversity of $P$. xuthus. Upper: male, Lower: female. Abbreviations on top or left of each row/column e.g. "EJ" or "WJ" are as same as those shown in figure legends. ${ }^{*}$ : the variance between 2 populations is not equal in 5\% normal significance level in Fdistribution. ${ }^{* *}$ : the variance between 2 populations is not equal in $1 \%$ normal significance level in F-distribution.

\begin{tabular}{|l|l|l|l|}
\hline \multicolumn{4}{|l|}{ P. macilentus } \\
\hline & Average & EJ & \\
\hline EJ & 18.833 & & \\
\hline
\end{tabular}

\begin{tabular}{|l|l|l|l|}
\hline & 64.645 & & \\
\hline \multirow{3}{*}{ WJ } & 18 & 0.833 & \\
\cline { 2 - 4 } & 57.692 & $-6.953^{*}$ & \\
\hline
\end{tabular}

Table 3: Diversity of $P$. macilentus. Upper: male, Lower: female. Abbreviations on top or left of each row/column e.g. "EJ" or "WJ" are as same as those shown in figure legends. ${ }^{*}$ : the variance between 2 populations is not equal in 5\% normal significance level in Fdistribution. ${ }^{* *}$ : the variance between 2 populations is not equal in $1 \%$ normal significance level in F-distribution.

\begin{tabular}{|c|c|c|c|c|}
\hline \multicolumn{5}{|c|}{ P. maackii } \\
\hline & Average & $\mathrm{HK}$ & EJ & WJ \\
\hline \multirow[b]{2}{*}{ HK } & 19.1 & & & \\
\hline & 40.333 & & & \\
\hline \multirow[b]{2}{*}{ EJ } & 22.769 & $3.669^{*}$ & & \\
\hline & 49.878 & $9.544^{*}$ & & \\
\hline \multirow[b]{2}{*}{ WJ } & 25.462 & $6.718^{\star *}$ & $2.692^{*}$ & \\
\hline & 55.214 & $14.881^{* *}$ & $5.337^{*}$ & \\
\hline \multirow[b]{2}{*}{ 9S } & 23.833 & $4.733^{* *}$ & -1.064 & -1.628 \\
\hline & 50.6 & $10.267^{*}$ & 0.722 & -4.614 \\
\hline
\end{tabular}

Table 4: Diversity of $P$ maackii. Upper: male, Lower: female. Abbreviations on top or left of each row/column e.g. "EJ" or "WJ" are as same as those shown in figure legends. ${ }^{*}$ : the variance between 2 populations is not equal in 5\% normal significance level in Fdistribution. ${ }^{* *}$ : the variance between 2 populations is not equal in $1 \%$ normal significance level in F-distribution.

\begin{tabular}{|c|c|c|c|c|c|c|c|}
\hline \multicolumn{8}{|c|}{ P. bianor } \\
\hline & $\begin{array}{l}\text { Averag } \\
\mathrm{e}\end{array}$ & $\mathrm{HK}$ & EJ & WJ & s9 & AM & OK \\
\hline \multirow{2}{*}{ HK } & 25 & & & & & & \\
\hline & 49.75 & & & & & & \\
\hline \multirow{2}{*}{ EJ } & 21 & -4.026 & & & & & \\
\hline & 60.064 & $10.314^{*}$ & & & & & \\
\hline \multirow{2}{*}{$\begin{array}{l}\text { W } \\
\mathrm{J}\end{array}$} & 24 & -1 & 3.026 & & & & \\
\hline & 62.056 & $12.306^{* *}$ & 1.992 & & & & \\
\hline \multirow{2}{*}{ s9 } & 20.5 & -4.500 * & -0.474 & -3.5 & & & \\
\hline & 53.333 & 3.583 & -6.73 & 8.722 & & & \\
\hline \multirow{2}{*}{$\begin{array}{l}\text { A } \\
M\end{array}$} & 13.333 & $-11.667^{\star *}$ & $-7.640^{*}$ & $-10.667^{\star *}$ & $-7.167^{\star *}$ & & \\
\hline & 38.111 & $-11.639^{* \star}$ & $-21.953^{\star *}$ & $-23.944^{\star *}$ & $-15.222^{* *}$ & & \\
\hline \multirow{2}{*}{$\begin{array}{l}\mathrm{O} \\
\mathrm{K}\end{array}$} & 13.375 & $-11.625^{\star *}$ & $-7.599^{* *}$ & $-10.625^{\star *}$ & $-7.125^{* *}$ & 0.042 & \\
\hline & 21.857 & ${ }_{*}^{-27.893^{*}}$ & $-38.207^{\star *}$ & $-40.198^{* *}$ & $-31.476^{\star *}$ & ${ }_{*} 16.254^{*}$ & \\
\hline
\end{tabular}


Citation: Inoue TA (2015) Geographical Diversity of Japanese Papilio Butterflies Inferred from the Number of Contact Chemosensillum on the Fifth Foretarsal Segments. J Biodivers Endanger Species S1: S1.007. doi:10.4172/2332-2543.S1-007

Page 3 of 10

\begin{tabular}{|l|l|l|l|l|l|l|l|}
\hline \multirow{2}{*}{$Y Y$} & 21.571 & -3.429 & 0.598 & -2.429 & 1.071 & $8.238^{* *}$ & $8.196^{* *}$ \\
\cline { 2 - 7 } & 61.556 & $11.806^{* *}$ & 1.492 & -0.5 & 8.222 & $\begin{array}{l}23.444^{*} \\
*\end{array}$ & $\begin{array}{l}39.698^{*} \\
*\end{array}$ \\
\hline
\end{tabular}

Table 5: Diversity of $P$. bianor. Upper: male, Lower: female. Abbreviations on top or left of each row/column e.g. "EJ" or "WJ" are as same as those shown in figure legends. *: the variance between 2 populations is not equal in $5 \%$ normal significance level in Fdistribution. ${ }^{* *}$ : the variance between 2 populations is not equal in $1 \%$ normal significance level in F-distribution.

\begin{tabular}{|l|l|l|l|l|}
\hline \multicolumn{2}{|l}{ P. helenus } \\
\hline \multirow{2}{*}{} & Average & EJ & WJ & AM \\
\hline \multirow{2}{*}{ EJ } & 19.84 & & & \\
\cline { 2 - 5 } & 108.625 & & & \\
\hline \multirow{2}{*}{ WJ } & 17.892 & -1.948 & & \\
\cline { 2 - 5 } & 109.378 & 0.753 & & \\
\hline \multirow{2}{*}{ AM } & 17.429 & -2.411 & -0.463 & \\
\cline { 2 - 5 } & 97.182 & $-11.443^{*}$ & -12.196 & \\
\hline \multirow{2}{*}{ OK } & 17.6 & -2.24 & -0.292 & 0.171 \\
\cline { 2 - 5 } & 93.833 & $-14.792^{* *}$ & $-15.544^{*}$ & -3.348 \\
\hline
\end{tabular}

Table 6: Diversity of $P$. helenus. Upper: male, Lower: female. Abbreviations on top or left of each row/column e.g. "EJ" or "WJ" are as same as those shown in figure legends. *: the variance between 2 populations is not equal in $5 \%$ normal significance level in $\mathrm{F}$ distribution. ${ }^{* *}$ : the variance between 2 populations is not equal in $1 \%$ normal significance level in F-distribution.

\begin{tabular}{|c|c|c|c|c|c|}
\hline \multicolumn{6}{|c|}{ P. protenor } \\
\hline & Average & EJ & WJ & AM & OK \\
\hline \multirow{2}{*}{ EJ } & 13.719 & & & & \\
\hline & 135.034 & & & & \\
\hline \multirow{2}{*}{ WJ } & 15.24 & 1.521 & & & \\
\hline & 143.063 & 8.028 & & & \\
\hline \multirow{2}{*}{ AM } & 17.5 & $3.781^{* *}$ & 2.26 & & \\
\hline & 131 & -4.034 & -12.063 & & \\
\hline \multirow{2}{*}{ OK } & 15 & 1.281 & -0.24 & -2.5 & \\
\hline & 131.333 & -3.701 & -11.729 & 0.333 & \\
\hline \multirow{2}{*}{ YY } & 13.667 & -0.052 & -1.573 & $-3.833^{* *}$ & -1.333 \\
\hline & 125.059 & -9.976 & -18.004 & -5.941 & -6.275 \\
\hline
\end{tabular}

Table 7: Diversity of $P$. protenor. Upper: male, Lower: female. Abbreviations on top or left of each row/column e.g. "EJ" or "WJ" are as same as those shown in figure legends. ${ }^{*}$ : the variance between 2 populations is not equal in $5 \%$ normal significance level in F-

distribution. ${ }^{* *}$ : the variance between 2 populations is not equal in $1 \%$ normal significance level in F-distribution.

\begin{tabular}{|c|c|c|c|}
\hline \multicolumn{4}{|c|}{ P. memnon } \\
\hline & Average & WJ & AM \\
\hline \multirow{2}{*}{ WJ } & 22.519 & & \\
\hline & 123.421 & & \\
\hline \multirow{2}{*}{ AM } & 25.7 & $3.181^{*}$ & \\
\hline & 145.1 & $21.679^{* *}$ & \\
\hline \multirow{2}{*}{ OK } & 23.556 & 1.037 & -2.144 \\
\hline & 128.556 & 5.135 & $-16.544^{*}$ \\
\hline
\end{tabular}

Table 8: Diversity of $P$. memnon. Upper: male, Lower: female. Abbreviations on top or left of each row/column e.g. "EJ" or "WJ" are as same as those shown in figure legends. ${ }^{*}$ : the variance between 2 populations is not equal in 5\% normal significance level in Fdistribution. ${ }^{* *}$ : the variance between 2 populations is not equal in $1 \%$ normal significance level in F-distribution.

\begin{tabular}{|c|c|c|c|c|}
\hline \multicolumn{5}{|c|}{ P. polytes } \\
\hline & Average & AM & OK & MY \\
\hline \multirow{2}{*}{ AM } & 18.667 & & & \\
\hline & 83.2 & & & \\
\hline \multirow{2}{*}{ OK } & 15.5 & -3.167 & & \\
\hline & 82.833 & -0.367 & & \\
\hline \multirow{2}{*}{ MY } & 19 & 0.333 & 3.5 & \\
\hline & 83.5 & 0.3 & 0.667 & \\
\hline \multirow{2}{*}{ YY } & 17 & -1.667 & 1.5 & -2 \\
\hline & 76.636 & -6.564 & -6.197 & -6.864 \\
\hline
\end{tabular}

Table 9: Diversity of $P$. polytes. Upper: male, Lower: female. Abbreviations on top or left of each row/column e.g. "EJ" or "WJ" are as same as those shown in figure legends. ${ }^{*}$ : the variance between 2 populations is not equal in 5\% normal significance level in Fdistribution. ${ }^{* *}$ : the variance between 2 populations is not equal in $1 \%$ normal significance level in F-distribution.

P. machaon chemosensilla numbers showed geographical diversity among female populations. The population variances for the east Hondo (Hokkaido including Rishiri Island, Tohoku, Kanto, Chubu, south Kinki, Izu islands and Sado island) and west Hondo (north Kinki, Chugoku, Shikoku, Kyushu, Awaji island, Oki islands, Tsushima islands, Iki islands, Goto islands, Koshiki islands, Kumage islands and Tokara islands) populations were significantly different at the $5 \%$ level (Figure 1). 


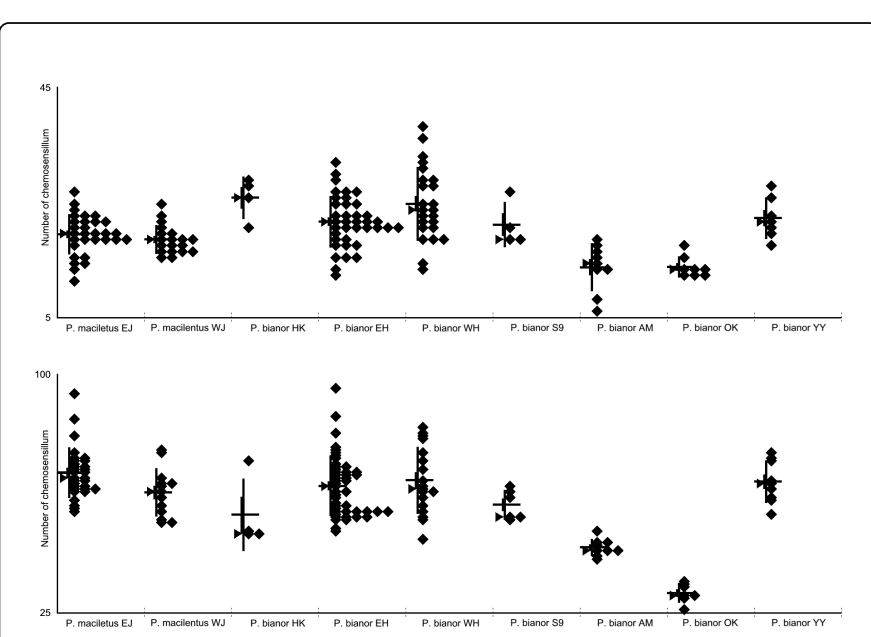

Figure 1: Variations in the fifth foretarsal contact chemosensillum numbers of Japanese Papilio machaon, $P$. xuthus and $P$. maackii shown in "stem and leaf" format. "': datum from each specimen plotted in sideways histogram, horizontal bar: means, long vertical bar: mean+/-SD, short vertical bar: mean +/-SE, “": median. Upper: male, lower: female. P. machaon EJ: P. machaon from east Hondo (=Hokkaidô including Rishiri Island, Tôhoku, Kantô, Chûbu, south Kinki, Izu Islands and Sado Island), P. machaon WJ: P. machaon from west Hondo (=north Kinki, Chûgoku, Shikoku, Kyûshû, Awaji Island, Oki Islands, Tsushima Islands, Iki Island, Gotô Islands, Koshiki Islands, Kumage Islands and Tokara Islands), $P$. xuthus EJ: $P$. xuthus from east Hondo, $P$. xuthus WJ: $P$. xuthus from west Hondo, P. xuthus SW: P. xuthus in the Nansei Is, P. maackii HK: $P$. maackii from Hokkaidô, $P$. maackii EH: $P$. maackii from east Hondo except Hokkaidô, $P$. maackii WH: $P$. maackii from west Hondo except Kyûshû, Tsushima Islands, Iki Islands, Gotô Isalands, Koshiki Islands and Kumage Islands, $P$. maackii 9S: P. maackii from Kyûshû, Tsushima Islands, Iki Islands, Gotô Islands, Koshiki Islands and Kumage Islands.

P. xuthus females also exhibited differences between east Hondo and west Hondo and the variances for these two populations were different at the 5\% significance level. Chemosensilla variances for west Hondo females and Nansei islands females were different at the $1 \%$ significance level; in contrast, the variances for east Hondo females and Nansei islands females were not significantly different (Figure 1). The differences among Amami islands populations, Okinawa islands populations and Yaeyama islands populations were not still confirmed because of the shortage of specimen of these areas.

$P$. macilentus female showed a similar diversity pattern to those of $P$. machaon and $P$. xuthus in Hondo (Figure 2). The chemosensilla variances for the east Hondo and west Hondo populations were different at the $5 \%$ significance level. The geographical boundary of east and west populations of these three species appears to be located along Wakasa bay, Biwa lake, Yodo river and Kii channel. This boundary is also applied to $P$. maackii, $P$. bianor, $P$. helenus, $P$. protenor and $P$. memnon. $P$. macilentus consists basically of one brood in Hokkaido and I could not examine the summer form of Hokkaidô $P$. macilentus in this study. Moreover I could not detect the differences between Hokkaidô and east Hondo except Hokkaido of both $P$. machaon and $P$. xuthus even I could examine 4 males and 3 females of summer form Hokkaido P. machaon and 3 males and 3 females of summer form Hokkaido P. xuthus.

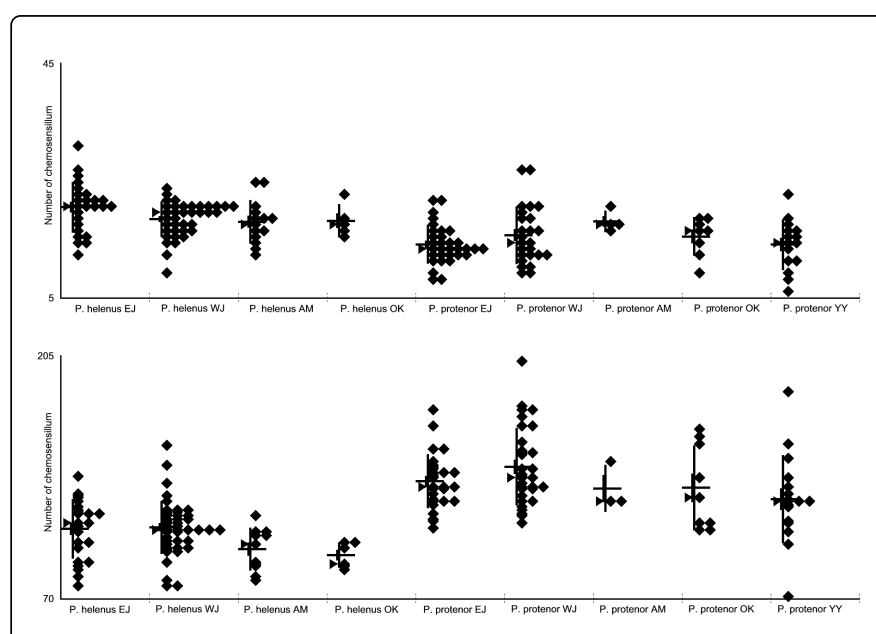

Figure 2: Variations in the fifth foretarsal contact chemosensillum numbers of Japanese $P$. macilentus and $P$. bianor shown in "stem and leaf" format. Upper: male, lower: female. P. macilentus EJ: $P$. macilentus from east Hondo, $P$. macilentus WJ: P. macilentus from west Hondo: $P$. bianor HK: P. bianor from Hokkaidô, $P$. bianor $\mathrm{EH}$ : $P$. bianor from east Hondo except Hokkaidô, P. bianor WH: $P$. bianor from west Hondo except Kagoshima Prefecture, P. bianor S9: $P$. bianor from Kagoshima Prefecture except Amami Islands, $P$. bianor AM: $P$. bianor from Amami Islands, P. bianor OK: $P$. bianor from Okinawa Islands, $P$. bianor YY: $P$. bianor from Yaeyama Islands.

For both sexes of $P$. maackii, the average contact chemosensillum numbers increased in an east-to-west pattern among the populations in Hokkaido, east Hondo except for Hokkaidô and west Hondo except for Kyushu, Tsushima Islands and Kumage islands, in contrast, the populations from Kyushu, Tsushima islands and Kumage islands did not show this tendency (Figure 1). Both male and female between Hokkaidô and West Japan except Kyushu, and male between Hokkaido and Kyushu were significantly different ( $1 \%$ level).

For both sexes of $P$. bianor, generally, the average contact chemosensillum numbers decreased in west Japan to Okinawa Islands, in contrast, the populations in Yaeyama Islands did not show this tendency. The male and female patterns were slightly different in some populations of $P$. bianor (Figure 2). For the females, the variance for the Okinawa Islands population was significantly different (1\% level) from the other populations (Hokkaido, east Hondo except Hokkaido, west Hondo except Kagoshima Prefecture, Kagoshima Prefecture except Amami islands, Amami islands, Yaeyama islands). Similarly the Amami islands population was significantly different (1\% level) from the other populations (Hokkaido, east Hondo except Hokkaido, west Hondo except Kagoshima Prefecture, Kagoshima Prefecture except Amami islands, Okinawa islands, Yaeyama islands). For males, the Okinawa Islands population was significantly different ( $1 \%$ level) from the other populations (Hokkaido, east Hondo except Hokkaido, west Hondo except Kagoshima Prefecture, Kagoshima Prefecture except Amami islands, Yaeyama islands) and not different from Amami islands population. The Amami islands population was different from the Kagoshima Prefecture except Amami islands and Yaeyama islands populations at the $1 \%$ significance level. The variances between Amami 
Citation: Inoue TA (2015) Geographical Diversity of Japanese Papilio Butterflies Inferred from the Number of Contact Chemosensillum on the Fifth Foretarsal Segments. J Biodivers Endanger Species S1: S1.007. doi:10.4172/2332-2543.S1-007

Page 5 of 10

islands male populations and east Hondo male populations except Hokkaido were different at the 5\% significance level.

For $P$. helenus, statistical differences were observed between the female populations from Hondo and those of Amami islands and Okinawa islands. The variances for the east Hondo and Okinawa islands were not the same at the $1 \%$ significance level. In addition, comparisons of variances for the east Hondo and Amami islands and for the west Hondo and Okinawa islands were different at the 5\% significance level (Figure 3).

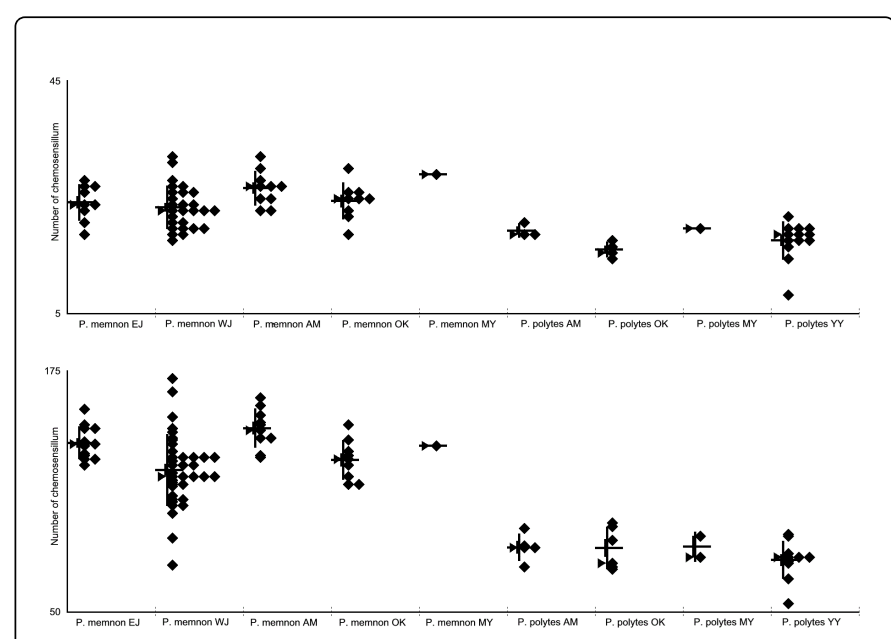

Figure 3: Variations in the fifth foretarsal contact chemosensillum numbers of Japanese $P$. Helenus and $P$. protenor shown in "stem and leaf" format. Upper: male, lower: female. $P$. helenus EJ: P. helenus from east Hondo, $P$. helenus WJ: $P$. helenus from west Hondo, $P$. helenus AM: $P$. helenus from Amami Islands, $P$. helenus OK: $P$. helenus from Okinawa Islands, $P$. protenor EJ: $P$. protenor from east Hondo, $P$. protenor WJ: $P$. protenor from west Hondo, $P$. protenor AM: $P$. protenor from Amami Islands, $P$. protenor OK: P. protenor from Okinawa Islands, $P$. protenor YY: $P$. protenor from Yaeyama Islands.

For $P$. protenor, the diversity patterns of the chemosensillum numbers for all male populations as well as the female populations from east Hondo, west Hondo and Yaeyama islands formed nearly normal distribution patterns. The average numbers for males increased continuously from east Hondo to Amami islands and decreased continuously from Amami islands to Yaeyama islands. For females, the west Hondo populations have more sensilla than east Hondo populations and Yaeyama islands populations have less than both Hondo populations. In contrast, the Amami islands and Okinawa islands populations showed irregular distribution patterns with two or three peaks (Figure 3). Comparisons of chemosensillum variances between east Hondo and Amami islands males, between Amami islands and Yaeyama islands males, and between west Hondo and Yaeyama islands females were all different at the $1 \%$ significance level.

For $P$. memnon, the variances for west Hondo females and Amami islands females were different at the $1 \%$ significance level and variance comparisons between west Hondo males and Amami islands males and between west Hondo females and Okinawa islands females were different at the $5 \%$ significance level (Figure 4 ).

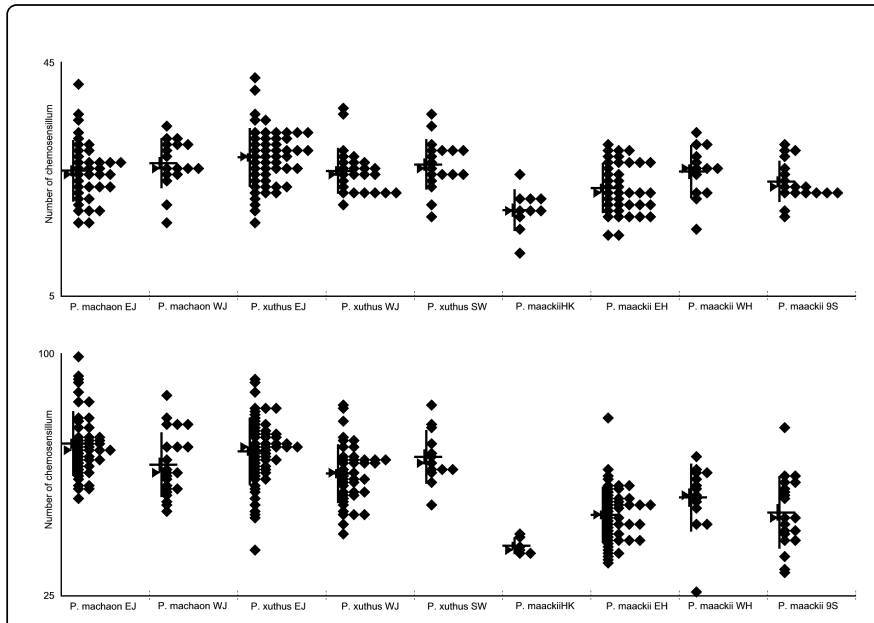

Figure 4: Variations in the fifth foretarsal contact chemosensillum numbers of Japanese $P$. memnon and $P$. polytes shown in "stem and leaf" format. Upper: male, lower: female. P. memnon EJ: P. memnon from east Hondo, $P$. memnon WJ: $P$. memnon from west Hondo, $P$. memnon AM: P. memnon from Amami Islands, $P$. memnon $\mathrm{OK}: P$. memnon from Okinawa Islands, $P$. memnon MY: $P$. memnon from Miyako Islands, $P$. polytes AM: $P$. polytes from Amami Islands, $P$. polytes $\mathrm{OK}: P$. polytes from Okinawa Islands, $P$. polytes MY: $P$. polytes from Miyako Islands, P. polytes YY: P. polytes from Yaeyama Islands.

Papilio polytes populations showed no significant differences for either sex (Figure 4).

For P. xuthus, P. helenus, $P$. macilentus and P. memnon, the diversity patterns of all of the male populations were the same as those of the females even though significant differences were not detected among the populations in these species. For $P$. machaon and $P$. helenus, the patterns of males were similar but not identical to those of the females.

\section{Discussion}

\section{The consistency between foretarsal morphology and the current taxonomy based on other phylogenetic characteristics}

P. machaon, $P$. xuthus and $P$. macilentus have been thought to have no geographical diversity in Japan [2-4]; however, my analysis of foretarsal morphology showed that these species can be divided into east Hondo populations and west Hondo populations, and this boundary does not correspond to any estimated biological boundary [70]. The average body sizes of both populations of each species are almost the same; thus, differences in chemosensillum numbers of these populations cannot be attributed to body size differences. The differences between Hondo and Nansei islands populations of $P$. xuthus were also first pointed out in this current of my article.

$P$. maackii was previously thought to have some geographical diversity although that had not been confirmed. P. maackii can be divided into four populations in Figure 1; however, the differences in the average contact chemosensillum numbers of the Hokkaido, east Hondo except Hokkaido and west Hondo except Kyushu, Tsushima islands and Kumage islands populations may be attributed to 
differences in their average body sizes. The reduced chemosensillum numbers for the Kyushu, Tsushima islands and Kumage islands population, whose average body sizes are the largest of the Japanese $P$. maackii, suggests that this population is independent from the other Japanese populations. These size differences are often thought to be caused by climate differences between the localities of these populations; however, individuals of each population reared from eggs in the same laboratory maintain their own characteristics for size and wing color scheme. This suggests that these differences are already fixed genetically. Some researchers say that west Japan $P$. maackii might be separated as $P$. maackii masuokai (e.g. [11]; the type locality is Ehime Pref., Shikoku), this must be still discussed carefully because Shikoku populations of $P$. maackii are included in that of West Japan except Kyushu in my study.

The geographical variations of Japanese $P$. bianor have already been researched and according to the last minute bibliographical research $[9,10]$ and some other evidence, Japanese $P$. bianor can be divided into four subspecies: $P$. bianor dehaanii (Hondo); P. bianor amamiensis (Amami islands); $P$. bianor ryukyuensis (Okinawa islands) and $P$. bianor okinawensis (Yaeyama islands). $[14,27,30]$ provided evidence of interpopulation hybridization in which, according to them, fertile hybrid females almost always occurred from crosses between adjacent island populations [71] reported that fertile $\mathrm{F} 1$ females originated from crosses between Hondo and Yaeyama islands populations, and this is the only exception at this point, [71] also reported that F3 females between $P$. polyctor in the Himalayas and $P$. bianor in Taiwan were fertile. In contrast, F1 females between $P$. polyctor in the Himalayas and $P$. bianor in Hondo were sterile [71]. Moreover, 5th instar larva of Amami islands and Okinawa islands populations resemble each other morphologically but are different from those of both Hondo and Yaeyama islands populations $[21,26,71]$. According to these findings, $P$. polyctor should be included in Taiwanese $P$. bianor, whereas, Japanese $P$. bianor might be separated into at least two subspecies groups. In this case, only $P$. bianor in Yaeyama islands would remain in $P$. bianor bianor group and the other populations might be $P$. bianor dehaanii group ([72] showed that $P$. bianor on Orchid islands and Green Islands are completely included in $P$. bianor on Main Taiwan). $P$. bianor amamiensis and $P$. bianor ryukyuensis are thought to form $P$. bianor ryukyuensis subspecies group and this is thought to be closer to $P$. bianor dehaanii subspecies group than $P$. binor bianor subspecies group. My current results showed continuous reduction of the number of fifth fortarsal ventral-side contact chemosensillum from west Japan to Okinawa Islands, thus these results generally support this grouping [73] divided Japanese Graphium doson (Papilionidea) into Yaeyama islands subspecies (spp perillus) and other Japanese subspecies (ssp albidum) including Amami islands, Okinawa Islands and Tsushima islands (ssp tsushimanus) populations, this also corresponds to my current results, [74] described these $P$. bianor subspecies groups as independent species, however, this is denied according to the intersubspecies hybridization results shown in [71]. The East Hondo populations, except for that of Hokkaido, may contain two different female races because two clear peaks can be seen (Figure 2); one peak is at a chemosensillum number of 49 and other at 65 . The peak at 49 is similar to one of the peaks of the Kagoshima Prefecture population, except for Amami islands, and that of the Hokkaido populations. Another south Kyushu peak seems to correspond to that of west Hondo populations with the exception of Kagoshima Prefecture. The relationship between these differences and minor geographical diversities in Hondo is not clear.
$P$. helenus is known for remarkable biodiversity in terms of wing shape, body size, number of red submarginal lunules on the hindwing and number of white patches in the center of the hindwings. It is divided into a number of subspecies $[43,60,75]$. Although studies of the differences between Hondo and Nansei islands populations are still insufficient compared with those of $P$. bianor, $P$. protenor and $P$. memnon, those were described as the introduction, [40,63-65] have already described the differences between the Hondo and AmamiOkinawa islands populations. According to their work, the differences appear in contrast of the adult wing color, the shape of the large yellow patch on the hindwings, and average body size. And the most important difference appears in the last instar larval color scheme, where that of the Amami-Okinawa islands population does not resemble either that of Hondo [76] or Taiwan populations [77] but is similar to that of the Philippine population [64-65,78]. Currently, the Japanese $P$. helenus populations are treated entirely as $P$. helenus nicconicolens; however, it may be possible to separate Nansei populations away from the Hondo populations as P. helenus orosius (Type locality is Amami-Oshima). My results seem to partially support this classification, but the average chemosensillum numbers decrease from north populations to south populations so the difference between Hondo and Nansei populations remains unclear.

From the results of geographical survey, Japanese $P$. protenor is separated into two subspecies: $P$. protenor demetrius from Hondo to Amami islands and $P$. protenor liukiuensis for Okinawa Islands and Yaeyama islands [3, type locality of ssp. liukiuensis is not clear]. These subspecies are also easily distinguished from each other by the shapes of the submarginal red lunules on the upper hindwings of the females and the length of the hindwing tail of both sexes [40,42]. Moreover, including my unpublished observations, the color scheme of the 2nd-4th instar larva of $P$. protenor in Okinawa islands and Yaeyama islands does not resemble that of either $P$. protenor in Hondo [42-43], Taiwan-China or other continental Asian Menelaides species such as $P$. helenus and $P$. nephelus [43]. In fact, it resembles that of $P$. polytes in Philippine-Maluku, and $P$. fuscus and $P$. aegeus in Maluku-AustralasiaMelanesia [43,78-84]. In contrast, that of $P$. protenor in Hondo and Amami islands is the same as that of both $P$. protenor in Taiwan-China and other continental Asian Menelaides species [43]. Overall, this current classification of $P$. protenor seems to be reasonable, but it does not fit my recent results. Although, the abnormal distribution pattern of sensillum numbers shown in Fig. 3 might be caused by the shortage of examined individuals, I propose that the origin of the current $P$. protenor of the Okinawa islands populations (and probably also of the Amami islands populations) is a hybrid between $P$. protenor from Yaeyama islands and from Hondo-(ancient) Amami islands. Hybridization experiments between Honshu and Yaeyama islands individuals revealed that female color patterns and the tail length of both sexes in hybrid butterflies resembled those of Yaeyama islands rather than those of Hondo $[42,43,52]$ which seems to support my hypothesis.

P. memnon also was divided into many subspecies and some peripheral populations are treated as independent species such as $P$. polymnestor, $P$. mayo, $P$. lowi and $P$. rumanzovia $[43,59]$. Here the geographical diversity and distribution resembled that of $P$. polytes and some other Southeast Asian butterflies [43,59,62,85-89]. The $P$. memnon female is well known to have many mimetic forms, whereas almost all Japanese females belong to $f$. agenor. The geographical variation of the Japanese $P$. memnon is not as remarkable as those of $P$. bianor and $P$. protenor, but some researchers have pointed out that in Japan the $f$. agenor females are whitest at the south end of their habitat, 
and become increasingly black toward the north end. For this reason the Japanese $P$. memnon was once divided into two subspecies, namely $P$. memnon pryeri (Okinawa islands and Amami islands) and $P$. memnon thunbergii [52]. Now all Japanese P. memnon are considered to be $P$. memnon thunbergii [8] because these differences are almost continuous. Japanese $P$. memnon females have one further characteristic; very few $\mathrm{f}$. achates have been collected from west Hondo and Nansei islands. Fortunately I was able to obtain this form in 2004 by rearing the larva of $P$. memnon sent to me by Mr. Ito Nobuo from "Flowerpark Kagoshima", Yamagawa, Kagoshima [90]. According to the reviews of [91,92] and [93], the notes of [94-102] and my own specimen, f. achates found in Nansei Islands, Nagasaki Prefecture and Shimane Prefecture are almost the same as those in continental Southeast Asia. In contrast, those found in South Kyushu and Tsushima islands have a reduced hindwing white patch area and the overall color is darker than those in continental Southeast Asia. The poison-eating butterflies as the models of $f$. achates (Pachliopta and some taild Parides species) and f. agenor (Idea leuconoe) do not occur in Hondo, on the other, Hondo P. memnon males prefer black females to white females [Hashimoto, Niki, Seta, unpublished]. So I think these darker $f$. achates and black $f$. agenor are established in Japan. The male color scheme in Hondo and Nansei islands is also slightly different from that found in continental Southeast Asia. From my results, both sexes do not correspond to the results for wing color pattern. The populations of east Hondo have been established in recent years (almost after 2000) and their origin is discussed [56,103]. In Figure 4, Hondo populations were divided into east and west Hondo populations in consideration of these discussions. The average for the east Hondo populations did not correspond to the average of the west Hondo populations but rather to the Amami islands population females. This should be considered when we estimate the quick spread and establishment of P. memnon in east Hondo. By these reason, the data from east Hondo population were not used for analysis to significant differences among populations using an F-distribution test.

Japanese $P$. polytes has been treated as $P$. polytes polycles and is now included in $P$. polytes polytes [6] because the large diversity in female wing patterns of this species is thought to result from mimicry. No other noticeable geographical difference between the continental Southeast Asian populations and the Japanese populations has been found. My result in Japan seems to support this classification; however, we must examine a Chinese and Southeast Asia specimen to confirm this relationship, and, of course, this is also required for all other species.

The data from $P$. demoleus specimens examined this time were not useful for revealing their diversity but might be useful for estimating the origin of these butterflies.

\section{Relations between foreleg morphology, geographical distribution patterns and host plant preference in females of each species}

When the reasons for the geographical diversity of the female foreleg morphology for every species are discussed, we must remember that chemoreception sensitivity is a chemical reaction that depends on temperature. With respect to female $P$. machaon, $P$. xuthus and $P$. macilentus, east Hondo individuals on average have more contact chemosensilla than those of west Hondo. This fact may show that east Hondo individuals of these species could retain sufficient sensitivity to detect their host plant correctly even in cooler temperature zone by increasing their chemosensilla. Even though $P$. machaon basically established in subarctic zone, East Asia $P$. machaon populations are sometimes thought they have already specialized from subarctic $P$. machaon populations, thus the fact that Japanese $P$. machaon populations show the diversity resembling to $P$. xuthus and $P$. macilentus those are thought to established in East Asia tempelature zone is reasonable. Some other geographical background also might affect these differences. The chemosensillum number diversity patterns of all Japan $P$. maackii and Hondo $P$. bianor resemble each other and are different from those of $P$. machaon, $P$. xuthus and $P$. macilentus. $P$. maackii and $P$. bianor already appear to have been well-adapted to cool-temperate zones more than East Asia P. machaon, $P$. xuthus and $P$. macilentus, thus the number of contact chemosensilla of these two species depend on the total body size. In contrast, the decrease in the contact chemosensilla of $P$. maackii in Kyushu and of $P$. bianor in South Kyushu seems to be caused by the high temperature in this area. In this climate, they seem to be able to maintain the sensitivity required to detect the correct host plants even though their contact chemosensilla are reduced. The temperature of Nansei islands is also high (or higher); however, in case of $P$. bianor, we should find another explanation for the variation in the chemosensillum numbers of $P$. bianor in these areas. P. bianor in Yaeyama islands is also known to be less selective regarding host plants [14] as occurs in Hondo. In contrast, $P$. bianor larvae on both Amami islands and especially on Okinawa islands often reject anything other than Euodia meliifolia as their host [15-21]. Although the average body sizes in these areas are often smaller than for either Hondo or Yaeyama islands, the noticeable reduction in female contact chemosensillum numbers in $P$. bianor Amami-Okinawa islands populations might relate to these peculiarities.

In the current study, I could not explain the difference of contact chemosensillum numbers in $P$. xuthus, $P$. helenus, $P$. protenor and $P$. memnon between Hondo and Nansei islands, or for those in $P$. protenor and $P$. memnon among Nansei islands populations, as well as those in P. helenus, $P$. protenor and P. memnon between east and west Hondo. In these cases, the sensillum number distributions in some populations showed more than one peak. Further studies of behavior and general physiology including neuronal responses by these species to plant components and their geographical history are required to resolve this issue.

Although the role of the male chemosensillum is still unknown, the similarity of chemosensillum number diversity between males and females is reasonable.

\section{Cause of phylogeny mismatch between DNA and other methods including my morphological work}

$[49,50,104]$ also proposed the phylogeny of P. bianor, P. (Papilio) species and $P$. protenor respectively. When DNA data are used for this purpose; however, we should consider that the accumulation of DNA mutations might depend on generation numbers rather than years. For example, every Papilio species in Kanto currently produces 2-4 generations per year, but in the glacial age it must have been $0.5-1$ generations per year and more than 5 generations in the warmest periods. Moreover, today $P$. bianor in Hokkaido produces $0.5-2$ generations per year, whereas that on Amami islands is 4 generations and on Yaeyama islands the number is increasing $[42,43]$. The number of generations will also be affected by wet/dry seasonal changes. In fact, $[47,49]$ showed that $P$. paris and $P$. maackii belong to the same cluster and $P$. bianor to another cluster. These findings do not correspond to previous results $[1,71]$ and the phylogenic trees of $P$. 
bianor and $P$. polyctor mentioned in $[47,49]$ correspond better to the differences in generations per year.

Another necessary correction appears in Figures 3 and 4 found in [50] which show the phylogeny of Menelaides and Iliads species. In these figures, the relationship of Japanese "black Papilio" is shown as " $((P$. polytes $+P$. memnon $)+(P$. protenor $+P$. macilentus $))+P$. helenus". This result, however seems to correspond somewhat to distribution patterns (basal metabolism amounts of these species) rather than phylogeny. As described above, the distribution areas of $P$. polytes and $P$. memnon superspecies almost overlap, especially these are the only South-East Papilio species those occur in both Andaman-Nicobar Islands and Maluku islands, and neither $P$. protenor nor $P$. macilentus do not occur in Malaysia where all other Southeast Asian Papilio species occur. The distribution area of $P$. helenus is similar to those of $P$. polytes and P. memnon superspecies; however, $P$. helenus does not occur in neither Andaman-Nicobar Islands nor Maluku islands. In addition, $P$. helenus has special distribution characteristics in that two sympatric species, $P$. iswara and $P$. iswaroides occur in Malay Peninsula, Borneo and Sumatra [85]. Without $P$. helenus, only P. paris shows a similar distribution with $P$. (Achillides) karna [85]. Moreover the close relationship between the $P$. machaon group and $P$. xuthus shown by $[50,104]$ also seems to be caused by the similarity of the habitats of these species rather than by their phylogenic relationship according to hybridization study [71,105-108]. $P$. xuthus is the only $P$. (Princeps) species occurring in the Asian temperature zone with $P$. machaon. All other Princeps occur in the Asia-Africa tropical and subtropical zones. Because butterflies are cold blooded creatures and oxygen inhalation is a chemical reaction whose velocity depends on temperature, the amount of oxygen inhalation per unit-time becomes necessarily larger in southern individuals than in northern ones. Mitochondrial enzymes relate directly to oxygen consumption, thus the phylogenies that they exhibit appear reasonable because they must originate from the convergence of mitochondrial enzymes. Moreover, DNA mutation is also a chemical reaction itself, thus the velocity of mutation accumulation in each cold-blooded animal must depend on the environmental temperature.

The problem with mt DNA phylogeny analysis is that an appropriate correction is not provided for the DNA results. The corrections provided by $[49-50,99]$ are solely for clock adjustment, not for dendrogram reconstruction and this might be the cause of the low bootstrap values and the "unexpected results" of the dendrograms in [49-50,99] and others. For Papilio butterflies, I think this correction will be more strictly required because the diversities both for numbers of generations per year and the habitat of each population of every Papilio species vary considerably and are influenced by many factors compared with other groups of butterflies. Fortunately, the phylogeny of genus Papilio has already been well estimated with many authentic methods such as interspecies hybridization or morphology as introduced in [1] and this article. Thus, we can find suitable ways for correcting DNA results by comparing these results with each other and this will be useful for the analysis of other groups of creatures.

\section{Appendix of my previous article, [1]}

A further survey of the literature provided the following studies of hybridization: among the $P$. machaon group [104]; between $P$. machaon and $P$. xuthus $[110,111]$; between $P$. maackii and $P$. bianor $[112,113]$; between $P$. maackii and $P$. machaon $[109,110]$; between $P$. helenus and $P$. polytes in the field $[114,115]$; between $P$. protenor and $P$. polytes [116], in the field [117] and in an insectarium [118,119]; between $P$. helenus and $P$. protenor [116]; between $P$. aegeus and $P$. fuscus [120]; between $P$. castor and P. hipponous in the field [121], illustrated as aberration of $P$. pitmani); between $P$. memnon and $P$. rumanzovia in the field [122]; and between $P$. memnon and $P$. helenus in the field [123]. Author of [124] succeeded to take a photo of mating $P$. maackii male and P. bianor female in the field. Moreover, [125] estimated the phylogeny of the Papilionidae of Japan from the morphology of the occipital region. All the above studies support my previous results [1] and this article.

\section{Acknowledgements}

I thank again all those people and institutes who I mentioned in my previous article [1]. Additionally I was helped by Ms. Sugiyama Yumiko (Ibaraki), Ms. Inokoshi Aya (Chiba), Mr. Tôyama Yutaka (Cho-ken), Mr. Uemura Yoshinobu (Tsukuba), Dr. Watanabe Seiji (Kashiwa), Mr. Nagahata Yoshiyuki (Yamagata), Mr. Abe Teruyuki (Nikkô), Mr. Iimura Takabumi (Nikkô), Ôsaka Museum of Natural History, Dr. Kanazawa Itaru (Ôsaka), Mr. Kojima Takeshi (Mie), $\mathrm{Mr}$ Kat Akihiko, and Mr. Kanai Ken-ichi (Amami) all of whom gave me new samples. Mr. Suka Takeshi (Nagano) provided me with information about animal distributions in Japan. Mr. Shimochi Hidetsugu (Miyako) gave me information about $P$. memnon in Miyako Islands and Mr. Fukuda Osamu (Fukuoka) gave me a information about P. macilentus in Fukuoka Pref. Mr. Hagiya Hiroshi (Tokyo) introduced me to the most recent results of geographical researches on Japan. Dr. Taniai Kiyoko (Tsukuba) allowed me to use the instrument that is necessary to carry out this work. Finally I also give my special thanks to Dr. Takeda Satoshi (Tsukuba, dead 2014) and Prof. Honda Kei-ichi (Hiroshima).

\section{References}

1. Inoue TA (2006) Morphology of foretarsal ventral surfaces of Japanese Papilio butterflies and relations between these morphology, phylogeny and hostplant preferring hierarchy. Zoological Science 23: 169-189.

2. Inomata T, Ibuki S (1980a) Synonimic catalogue of the butterflies of Japan. Gekkan Mushi 111: 29-32.

3. Inomata T, Ibuki S (1980b) Synonimic catalogue of the butterflies of Japan. Gekkan Mushi 112: 27-30.

4. Inomata T, Ibuki S (1980c) Synonimic catalogue of the butterflies of Japan. Gekkan Mushi 115: 25-28.

5. Inomata T, Ibuki S (1980d) Synonimic catalogue of the butterflies of Japan. Gekkan Mushi 116: 33-34.

6. Inomata T, Ibuki S (1980e) Synonimic catalogue of the butterflies of Japan. Gekkan Mushi 118: 17-19.

7. Inomata T, Ibuki S (1981a) Synonimic catalogue of the butterflies of Japan. Gekkan Mushi 121: 27-29.

8. Inomata T, Ibuki S (1981b) Synonimic catalogue of the butterflies of Japan. Gekkan Mushi 125: 27-29.

9. Inomata T, Ibuki S (1981c) Synonimic catalogue of the butterflies of Japan. Gekkan Mushi 128: 23-24.

10. Inomata T, Ibuki S (1981d) Synonimic catalogue of the butterflies of Japan. Gekkan Mushi 129: 27-31.

11. Inomata T, Ibuki S (1982) Synonimic catalogue of the butterflies of Japan. Gekkan Mushi 135: 19-22.

12. Ae AS (1980) Hybrid butterflies and formation of species. The Rhopalocerist's Magazine 3: 37-46.

13. Waki I (1980a) Rearing records of Achillides butterflies. Kanagawa Chûhô 60: 1-18.

14. Waki I (1986a) Papilio bianor complex, distribution and variation in Japan. The nature and insects 21: 4-8. 
15. Waki I (1993) Notes on Papilio butterflies Rearing of P. bianor from Amami and Okinawa. Jesutio 72: 3-5.

16. Ashizawa I (1993) Notes on Papilio butterflies Rearing of P. bianor from Amami and Okinawa. Jesutio 72: 6.

17. Kobori F (1993) Notes on Papilio butterflies, Rearing of P. bianor from Amami and Okinawa. Jesutio 72: 8-9.

18. Konno K (1993) Notes on Papilio butterflies; Rearing of P. bianor from Amami and Okinawa. Jesutio 72: 10-12.

19. Matsui Y, Matsui H (1993) Notes on Papilio butterflies; Rearing of P. bianor from Amami and Okinawa. Jesutio 72: 7.

20. Ôshima Y (1993) Notes on Papilio butterflies; Rearing of P. bianor from Amami and Okinawa. Jesutio 72: 7.

21. Hama S (1976) Preliminary investigation of the intraspecies hybridization of Papilio bianor between Osaka and Okinawa. MDK News 26: 12-16.

22. Waki I (1980b) Variations of the last instar larva of Achillides group. The Rhopalocerist's Magazine 3: 35-41.

23. Waki I (1981) Hybridization study on Achillides group. The Rhopalocerist's Magazine 4: 5-10.

24. Waki I (1986b) Papilio bianor complex, distribution and variation in Japan. The nature and insects 21: 11-15.

25. Waki I (1986c) Papilio bianor complex, distribution and variation in Japan. The nature and insects 21:26-31.

26. Waki I (1987a) Papilio bianor complex, distribution and variation in Japan. The nature and insects 22: 16-20.

27. Waki I (1987b) Papilio bianor complex, distribution and variation in Japan. The nature and insects 22: 20-24.

28. Waki I (1987c) Papilio bianor complex, distribution and variation in Japan. The nature and insects 22: 2-10.

29. Ichinose T, Horiuchi C (1985) Alloptric Speciation of Yaeyama Insular Isolates in the Papilio bianor Complex of Japan. Kontyû 53: 233-244.

30. Ae SA (1990) A study of the Papilio bianor group mainly based on Hybridization (Lepidoptera, Papilionidae). Tyoto Ga 41: 13-19.

31. Ae SA (1995) Ecological and evolutionary aspects of hybridization in some Papilio Butterflies. In: Scriber JM, Tsubaki Y, Lederhouse RC (eds) Swallowtail butterflies. Scientific Publishing, Gainesville. 229-235 pp.

32. Ejima M (1978) Butterflies and their ecology in Nagasaki Pref. Gekkan Mushi 83: 9-16.

33. Waki I (1982a) The morphology of the pupa of Papilio bianor in Japan. The Rhopalocerist's Magazine 5: 8-17.

34. Waki I (1982b) The morphology of the pupa of Papilio bianor in Isigaki Jima. The Rhopalocerist's Magazine 5: 9.

35. Waki I (1982c) Rearing records of Achillides butterflies 2. Kanagawa Chûhô 67: 1-16.

36. Inoue T (1985) Note of Papilio butterflies 3. Jesutio 9: 1-6.

37. Ashizawa I (1987) The shape of Papilio bianor Pupa in Mie Pref. Hyakutorimushi, 385.

38. Ashizawa I (1989) The black lines in the prolegs of last instar larva of $\mathrm{P}$ bianor from Tokara Is. Cho-ken Field 4: 27-28.

39. Ashizawa I, Inoue T, Waki I (1988) The black lines in the prolegs of last instar larva of P. bianor. Cho-ken Field 3: 20-22.

40. Kawazoe A, Wakabayashi M (1976) Coloured illustrations of the butterflies of Japan. Hoikusha, Osaka.

41. Azuma S, Minato K (1983) Butterflies of Ryukyus. Shinsei-Shuppan, Naha, Japan.

42. Fukuda H, Hama E, Kuzuya K, Takahashi A, Takahashi M, et al. (1982) The life histories of Butterflies in Japan. Hoikusha, Osaka.

43. Igarashi S (1979) Papilionidae and their early stages. Kodansha, Tokyo.

44. Kominami H, Yamaguchi O, Sumiyoshi K (1987) Species diversity in the island populations of Papilio bianor complex in Japan considered from gene flow and genetic distance. Tyoto Ga 38: 269-286.

45. Kominami H, Kasahara M, Sumiyoshi K, Yamaguchi O (1991) Protein variability detected by SDS-Polyacrylamide gel electrophoresis in subspecies of Papilio bianor Cramer. Tyoto Ga 42: 1-9.
46. Yagi T (2001a) Formation of Papilionid butterfly distribution relevant to paleogeography in the Ryukyu islands deduced from mitochondrial DNA sequences. The nature and insects 36: 37-41.

47. Yagi T (2001b) Molecular phylogeny, taxonomy and natural history of subgenus Achillides (Lepidoptera: Papilionidae: Papilio). The nature and insects 36: 9-12.

48. Yagi T (2003) Formation of Papilionidae distribution in Japan referred from DNA phylogenetics. Gekkan Mushi 386: 22-29.

49. Yagi T, Sasaki G, Omoto K (2006) Phylogeny, biogeography and wing pattern convergence of the subgenus Achilides (Lepidoptera, Papilionidae, Papilio) revealed by a mitochondrial DNA sequence analysis. Transaction of the Lepidopterological Society of Japan 57: 137-147.

50. Yagi T, Sasaki G, Takebe H (1999) Phylogeny of Japanese Papilionid butterflies inferred from Nucleotide sequences of the mitochondrial ND5 gene. Journal of the Molecular Evolution 48: 42-48.

51. Izumi K, Kano K, Sasaki K (1984) Studies on the geographic variation of wing shape in Papilio bianor by principal component analysis. Tyôto Ga 34: $155-162$.

52. Hachiya Y (1974) Notes on Papilio memnon and P. protenor from Okinawa. Yadoriga 79: 20-22.

53. Ichinose T, Iwasaki N (1979) Pupal diapause in some Japanese Papilionid butterflies III. The difference in the temperature of diapause between the two subspecies of Papilio protenor Cramer and their Development. Kontyu 47: 272-280.

54. Ichinose T, Negishi H (1979) Pupal diapause in some Japanese Papilionid butterflies II. The difference in the induction of diapause between the two subspecies of Papilio protenor Cramer. Kontyu 47: 89-98.

55. Seta K (2001) A study on hybridization of Papilio protenor demetrius Stoll and P. p. liukiuensis Fruhstorfer (Lepidoptera, Papilionidae). Transaction of the Lepidopterological Society of Japan 52: 288-291.

56. Yoshio M, Ishii M (1998) Geographical variation of Pupal diapause in the great mormon butterfly, Papilio memnon L. (Lepidoptera: Papilionidae), in Western Japan. Applied Entomology and Zoology 33: 281-288.

57. Takahashi A, Ishida S (1969) Papilio memnon from the Sakishima Islands. Tyoto Ga 20: 61-65.

58. Tanaka H, Tanaka A (1970) Female Papilio memnon from Tokara Is with white patch in their hindwings distal area. Tyoto Ga 21: 57-59.

59. Morishita K (1973) Papilio memnon. Yadoriga 76: 3-10.

60. Uehara T (1975) Papilio maackii of Tsushima Is. Gekkan Mushi 53: 6-7.

61. Yanagisawa T (2002) Papilio maackii. Bokkei, Tokyo.

62. Morishita K (1974) Papilio helenus. Yadoriga 77: 7-14.

63. Ae SA (1981) Notes on Papilio butterflies in Ryukyu Islands. Ryukyu no Kontyu 5: 1-4.

64. Inoue T (1993) Notes on Papilio butterflies 6-1. Menelaides butterflies in Hokuriku area of Japan. Jesutio 70: 2-9.

65. Taira A (2001) Tectonic evolution of the Japanese Island arc system. Annu Rev Earth Planet Sci 29: 109-134.

66. Osozawa S, Shinjo R, Armid A, Watanabe Y, Horiguchi T, et al. (2012) Palaeogeographic reconstruction of the 1.55 Ma synchronous isolation of the Ryukyu Islands, Japan, and Taiwan and inflow of the Kuroshio warm current. International Geology Review 54: 12.

67. Kamiya K (1984) Geographical history of Ryukyu islands. Shinsei-Tosho, Naha.

68. Wakimoto K, Tarumi T, Tanaka Y (1984) Handbooks of stastical analysis on Personal computers 1. Kyohritsu Shuppan Co. Ltd, Tokyo.

69. Haga T, Hashimoto $S$ (1980) The bases of statistics programming. Nihon Giren Shuppan, Tokyo.

70. Tokuda M (1969) Biogeography. Tsukiji Shokan, Tokyo.

71. Hasegawa M, Ae SA (2003) Swallowtails -hybridization and genetics in Papilionid butterflies- (18th special exhibition). Toyohashi Museum of Natural History, Toyohashi.

72. Chang YJ (1990) A study on hybridization of two subspecies of Papilio bianor (Lepidoptera, Papilionidae) in Taiwan. Tyoto Ga 41: 1-6. 
Citation: Inoue TA (2015) Geographical Diversity of Japanese Papilio Butterflies Inferred from the Number of Contact Chemosensillum on the Fifth Foretarsal Segments. J Biodivers Endanger Species S1: S1.007. doi:10.4172/2332-2543.S1-007

Page 10 of 10

73. Osada Y, Yago M, Yata O, Hirowatari T (2015) Comparison of the male and female genitaria and DNA barcoding between Japanese subspecies of Graphium doson (C. Felder \& R. Felder) (Lepidoptera, Papilionidae), with determination of the subspecies of the Okinawa-jima and Tsyshima Island populations. Lepidoptera Science 66: 26-42.

74. JBCS (2012) Field Guide to the Butterflies of Japan (2nd Ed). SeibundouShinkousha, Tokyo.

75. Shirôzu T (1960) Buttrflies of Formosa in colour. Hoikusha, Ôsaka.

76. Shirôzu T, Hara A (1962) Early stages of Japanese butterflies in color 2. Hoikusha, Ôsaka.

77. Lee JY (1991) The illustrations of butterflies in Taiwan 2. Publishing section of Museum of Taiwan, Taipei. (in Chinese)

78. Ae SA (1978) A study on the immature stages and diapause of Papilionid and other butterflies of the Philippines. Tyoto Ga 29: 227-236.

79. Ae SA (1977) Immature stage and genetics of Papilio hipponous (Lepidoptera: Papilionidae). Tyoto Ga 28: 147-150.

80. Gunji Y (1973) A trip to Maluku. Yadoriga 76: 11-25.

81. Sugimoto M (1993) The rearing of Papilio alphenor from Japan. Cho-ken Field 8: 11-13

82. Inoue T (1997) Rearing of Papilio fuscus. Jesutio 112: 2-5.

83. Inoue TA (2000) Butterflies observed in Australia in 1999. Jesutio 135: $2-14$.

84. Inoue TA (2008) Research project on South Pacific Papilio butterflies. Jesutio 185: 1-19.

85. Tsukada E, Nishiyama Y (1980) Butterflies of the South East Asian Islands 1 (Papilionidae). Prapack, Tokyo.

86. Morishita K, Yata O (1981) Butterflies of the South East Asian Islands 2. Prapack, Tokyo.

87. Aoki T (1982) Butterflies of the South East Asian Islands 3. Prapack, Tokyo.

88. Tsukada E (1985) Butterflies of the South East Asian Islands 4. Prapack, Tokyo.

89. Tsukada E (1991) Butterflies of the South East Asian Islands 5. Azumino Butterfly research institute, Matsumoto.

90. Inoue TA (2005b) Evolutional analysis of the mimicry of "black" Papilio butterflies from the aspect of interspecies hybridization. The nature and insects 40: 14-17.

91. Fukuda H, Nichô K (1985) Preliminary notes on the tailed females of the Great Mormon Papilio memnon L. (Papilionidae, Lepidoptera) in Japan 1. Bulletin of the Kagoshima Museum 4: 1-21.

92. Fukuda H, Nichô K (1986) Preliminary notes on the tailed females of the Great Mormon Papilio memnon L. (Papilionidae, Lepidoptera) in Japan 2. Bulletin of the Kagoshima Museum 5: 9-14.

93. Fukuda H (2000) Tailed-form female of Papilio memnon in Japan. The nature and insects 35: 33-35.

94. Koizumi M (1989) I captured tailed form of Papilio memnon female in Amami-Ôshima. Cho-ken Field 4: 26.

95. Yodoe K (1989) Tailed form Papilio memnon female attributed collecting in Hamada city. Cho-ken Field 4: 16-17.

96. Shibukawa K (1990) Whitey Papilio memnon from Iriomote Jima. Choken Field 5: 20-21.

97. Matsuda T, Matsuda Y (1992) I captured tailed form of Papilio memnon female. Cho-ken Field 7: 26.

98. Fujino T (1993) I captured tailed form of Papilio memnon female in Amami Ôshima. Cho-ken Field 8: 26.

99. Bamba H (1995) I collected Papilio memnon female f. achates in Amami Ôshima. Cho-ken Field 10: 31.

100. Hayashi $T$ (1996) I collected Papilio memnon female f. achates in Yonaguni Jima. Cho-ken Field 11: 29-30.
101. Satou T (1997) I collected Papilio memnon female f. achates in Tsushima. Cho-ken Field 12: 31.

102. Tsukakoshi A (1997) The record of Papilio memnon female f. achate. Cho-ken Field 12: 30.

103. Kitahara M, Iriki M, Gou S (2001) On the relationship between the northward distributional expansion of the great mormon butterfly, Papiolio memnon Linnaeus, and climate warming in Japan. Transaction of the Lepidopterological Society of Japan 52: 253-264.

104. Yagi T, Fujioka T (2005) Classification and Molecular phylogeny of Subgenus Papilio (Papilionidae, Papilio). The nature and insects 40: 3942.

105. Watanabe K (1968) A study of interspecific hybrids between Papilio machaon hippocrates female, and P. xuthus male. Tyoto Ga 19: 25-28.

106. Asawa N (1969) A study of interspecific hybrids between Papilio machaon \& P. xuthus male. The nature and Insect 4: 28-30.

107. Inoue $T$ (1983) A study of interspecific hybrids among Papilio butterflies -1. The Rhopalocerist's Magazine 6: 37-40.

108. Inoue T (1991) Note on Papilio butterflies (4). Jesutio 46: 2- 13.

109. Remington CL (1956) Interspecific relationships of two rare swallowtail butterflies, Papilio nitra and Papilio hudsonicus, to other members of Papilio machaon complex. Year book of the American Philosophical Society (1956), 142-146.

110. Koide Y (1991) The swallowtails of the world form machaon note. The nature and insects 26: 15-24.

111. Zakharov EV (1997) About experimental hybridization between Achillides maackii (Men.), Sinoprinceps xuthus (L.), and Papilio machaon L. (Lepidoptera: Papilionidae). Fauna and flora of the Russian Far East. Scientific reports of Ussuryisky State Pedagogical Institute Ussuryisk Issue 3: 12-21.

112. Waki I (1983) A study of interspecific hybrids between Papilio maackii and P. bianor. The Rhopalocerist's Magazine 6: 25-34.

113. Yamada A (1977) A study of interspecific hybrids between Papilio bianor and P. maackii. The nature and insects 12: 27-28.

114. Tomikawa K (1988) Abnormal wing color pattern Papilio polytes. Choken Field 3: 34-35.

115. Arata S (1994) Butterflies collected in Fui-Jima, Nakijin, Okinawa. Choken Field 9: 17-18.

116. Inoue $\mathrm{T}$ (1992) Note of Papilio butterflies 5. Jesutio 54: 9-16.

117. Tanikado M (1986) Abnormal wing color pattern Papilio polytes. Choken Field 1: 37.

118. Ishijima A (1996) Hybrid butterflies between Papilio polytes and P. protenor. Insectarium 33: 116-117.

119. Sakamoto $N$ (2006) Hybrid butterflies had appeared. Itakon 3: 6 .

120. Straatman R (1962) A hybrid between Papilio aegeus aegeus and Papilio fuscus capaneus, with a note on larval foodplants. Journal of the Lepidopterists' Society 16: 161-174.

121. Ek-Amnuay P (2006) Butterflies of Thailand. Amarin Book Center Co Ltd, Bangkok.

122. Fujita K (2005) Abnormal wing color pattern Papilio memnon collected in Yonakuni Jima. Cho-ken Field 20: 12.

123. Suzuki S (2007) I captured hybrid butterfly between Papilio memnon and P. helenus in the field. Cho-ken Field 22: 27

124. Takeuchi G (2008) Butterflies in Gamagori. Sanjudo, Aichi.

125. Tsubuki T, Koyama N (1982) Structure of the occipital region in Papilionidae (Lepidoptera) from Japan. Kontyu 50: 23-34. 